\title{
Role of ERK/MAPK in endothelin receptor signaling in human aortic smooth muscle cells Qing-wen Chen ${ }^{1,2}$, Lars Edvinsson ${ }^{1,2}$ and Cang-Bao $\mathrm{Xu}^{* 1}$
}

\begin{abstract}
Address: ${ }^{1}$ Division of Experimental Vascular Research, Institute of Clinical Science in Lund, Lund University, Lund, Sweden and ${ }^{2}$ Department of Clinical and Experimental Research, Glostrup Hospital, Copenhagen University, Copenhagen, Denmark

Email: Qing-wen Chen - cherqw@hotmail.com; Lars Edvinsson - Lars.Edvinsson@med.lu.se; Cang-Bao Xu* -Cang-Bao.Xu@med.lu.se

* Corresponding author
\end{abstract}

Published: 3 July 2009

BMC Cell Biology 2009, 10:52 doi:10.1 I86/147/-2/2I-10-52
Received: 27 February 2009

Accepted: 3 July 2009

This article is available from: http://www.biomedcentral.com/I47I-2I $2 \mid / 10 / 52$

(c) 2009 Chen et al; licensee BioMed Central Ltd.

This is an Open Access article distributed under the terms of the Creative Commons Attribution License (http://creativecommons.org/licenses/by/2.0), which permits unrestricted use, distribution, and reproduction in any medium, provided the original work is properly cited.

\begin{abstract}
Background: Endothelin-I (ET-I) is a potent vasoactive peptide, which induces vasoconstriction and proliferation in vascular smooth muscle cells (VSMCs) through activation of endothelin type $A$ $\left(E_{A}\right)$ and type $B\left(E T_{B}\right)$ receptors. The extracellular signal-regulated kinase I and $2(E R K I / 2)$ mitogen-activated protein kinases (MAPK) are involved in ET-I-induced VSMC contraction and proliferation. This study was designed to investigate the $\mathrm{ET}_{\mathrm{A}}$ and $\mathrm{ET}_{\mathrm{B}}$ receptor intracellular signaling in human VSMCs and used phosphorylation (activation) of ERKI/2 as a functional signal molecule for endothelin receptor activity.
\end{abstract}

Results: Subconfluent human VSMCs were stimulated by ET-I at different concentrations (I nMI $\mu \mathrm{M})$. The activation of ERKI/2 was examined by immunofluorescence, Western blot and phosphoELISA using specific antibody against phosphorylated ERKI/2 protein. ET-I induced a concentration- and time- dependent activation of ERKI/2 with a maximal effect at $10 \mathrm{~min}$. It declined to baseline level at $30 \mathrm{~min}$. The ET-I-induced activation of ERKI/2 was completely abolished by MEKI/2 inhibitors U0I 26 and SL327, and partially inhibited by the MEKI inhibitor $\mathrm{PD}$ 98059. A dual endothelin receptor antagonist bosentan or the $\mathrm{ET}_{\mathrm{A}}$ antagonist $\mathrm{BQ} / 23$ blocked the ET-I effect, while the $\mathrm{ET}_{\mathrm{B}}$ antagonist $\mathrm{BQ788}$ had no significant effect. However, a selective $\mathrm{ET}_{\mathrm{B}}$ receptor agonist, Sarafotoxin 6c (S6c) caused a time-dependent ERKI/2 activation with a maximal effect by less than $20 \%$ of the ET-I-induced activation of ERKI/2. Increase in bosentan concentration up to $10 \mu \mathrm{M}$ further inhibited ET-I-induced activation of ERKI/2 and had a stronger inhibitory effect than BQI23 or the combined use of BQI23 and BQ788. To further explore ET-I intracellular signaling, PKC inhibitors (staurosporin and GFI09203X), PKC-delta inhibitor (rottlerin), PKA inhibitor ( $\mathrm{H}-89$ ), and phosphatidylinositol 3-kinase (PI3K) inhibitor (wortmannin) were applied. The inhibitors showed significant inhibitory effects on ET-I-induced activation of ERK I/2. However, blockage of L-type $\mathrm{Ca}^{2+}$ channels or calcium/calmodulin-dependent protein kinase II, chelating extracellular $\mathrm{Ca}^{2+}$ or emptying internal $\mathrm{Ca}^{2+}$ stores, did not affect ET-I-induced activation of ERKI/2.

Conclusion: The $\mathrm{ET}_{\mathrm{A}}$ receptors predominate in the ET-I-induced activation of ERKI/2 in human VSMCs, which associates with increments in intracellular PKC, PKA and PI3K activities, but not $\mathrm{Ca}^{2+}$ signalling. 


\section{Background}

In the human cardiovascular system, endothelin-1 (ET-1) is the most important isoform, which induces long-lasting vasoconstriction and stimulates proliferation of vascular smooth muscle cells (VSMCs) [1]. ET-1 acts on two G-protein coupled receptors: endothelin type $\mathrm{A}\left(\mathrm{ET}_{\mathrm{A}}\right)$ and endothelin type $\mathrm{B}\left(\mathrm{ET}_{\mathrm{B}}\right)$, and plays an important role in hypertension, vascular remodelling, cardiac hypertrophy and coronary artery disease [2]. The $\mathrm{ET}_{\mathrm{A}}$ receptors locate on VSMCs and mediate vasoconstriction, while the $\mathrm{ET}_{\mathrm{B}}$ receptors primarily locate in vascular endothelial cells and mediate transient vasodilation in vivo [3]. However, a subpopulation of contractile $\mathrm{ET}_{\mathrm{B}}$ receptors exist in the VSMCs and mediate vasoconstriction $[3,4]$. The $\mathrm{ET}_{\mathrm{A}}$ receptor activates $G$ proteins of $\mathrm{Gq} / 11$ and $\mathrm{G} 12 / 13$, which results in the contractile and proliferation effects in VSMCs through activation of diverse signaling molecules such as phospholipase C (PLC), intracellular $\mathrm{Ca}^{2+}$, protein kinase $\mathrm{C}$ (PKC), and extracellular signal-regulated kinase 1 and 2 (ERK1/2). Whereas, the $\mathrm{ET}_{\mathrm{B}}$ receptor stimulates the Gi and the Gq/11 families in VSMCs and endothelial cells $[1,2,5,6]$. ET-1 is non-selective agonist for both $\mathrm{ET}_{\mathrm{A}}$ and $\mathrm{ET}_{\mathrm{B}}$ receptors, which may result in receptor signal crosstalk in vascular physiology and pathology. However, there is limited knowledge about this.

ERK1/2, also termed p44/42 MAPK (mitogen-activated protein kinase), is one of the members of MAPK superfamily, which includes a family of serine/threonine kinase associated with VSMCs contraction, proliferation, migration, differentiation, adhesion, collagen deposition and survival [7]. Activation of either the $\mathrm{ET}_{\mathrm{A}}$ or the $\mathrm{ET}_{\mathrm{B}}$ receptor results in phosphorylation of ERK1/2, which is an important regulator for cellular proliferation, migration, differentiation and vascular smooth muscle constriction [8-12]. A MAPK kinase (MEK) is required for the ERK1/2 phosphorylation of both threonine and tyrosine residues [13]. In the activated form, ERK1/2 transmits extracellular stimuli by phosphorylating a variety of substrates including transcription factors and kinases. There is a paucity of knowledge on intracellular signal mechanisms that ET-1 leads to activation of ERK1/2 in human VSMCs. Nonreceptor tyrosine kinase c-Src-independent small G protein Ras-Raf-dependent mechanisms have been reported to mediate ET-1-induced ERK1/2 phosphorylation in cultured mouse VSMCs [14]. Intracellular $\mathrm{Ca}^{2+}$ signals are required for MAPK/ERK1/2 activation induced by angiotensin II in VSMCs [15-17]. However, ET-1-induced vasoconstriction is not affected by calcium channel blockers [18]. Thus, $\mathrm{Ca}^{2+-}$-independent contraction is suggested to be associated with $\mathrm{PKC}$, phosphoinositide 3-kinase (PI3K), Rho kinase and MAPK $[10,11,19]$. The present study was designed, by using a series of specific pharmacological inhibitors, to explore the intracellular signal mechanisms that ET-1 leads to activation of ERK1/2 in human VSMCs with special focus on the receptor signal- ling. We have demonstrated that $\mathrm{ET}_{\mathrm{A}}$ receptors predominate over $\mathrm{ET}_{\mathrm{B}}$ receptors in mediating ET-1-induced activation of ERK1/2 in human VSMCs. This activation is associated with PKC, PKA and PI3K activities, but not intracellular $\mathrm{Ca}^{2+}$ signalling.

\section{Results \\ Time course and concentration-dependent activation of $E R K I / 2$ induced by $E T-I$}

ET-1-induced activation of ERK1/2 was examined in human aortic smooth muscle cells (HASMCs) at different time points and ET- 1 concentrations. There was a 2.6 fold ( $p<0.001)$ increase of phosphorylated ERK1/2 in cells exposed to $1 \mu \mathrm{M}$ of ET-1 for $5 \mathrm{~min}$; the enhancement reached a peak ( 3.6 fold, $\mathrm{p}<0.001$ ) at $10 \mathrm{~min}$ after exposure to ET-1 (Figure 1A). Thereafter, the activities of ERK1/ 2 induced by ET-1 rapidly declined, and returned to baseline control value at $30 \mathrm{~min}$ after stimulation. As verified by western blot (Figure 1B), there was an increase in pERK1/2 after ET- 1 treatment. The concentration effects of ET-1 on ERK1/2 activation were investigated at $10 \mathrm{~min}$. It showed that ET-1 induced activation of ERK1/2 in a concentration-dependent manner from $1 \mathrm{nM}$ to $1 \mu \mathrm{M}$ (Figure 1C).

\section{Roles of endothelin receptors in mediating ET-I-induced activation of ERKI/2}

The roles of $\mathrm{ET}_{\mathrm{A}}$ and $\mathrm{ET}_{\mathrm{B}}$ receptors in mediating ET-1induced activation of ERK1/2 were studied by using bosentan (a dual endothelin receptor antagonist), BQ123 (a selective peptide antagonist for the $\mathrm{ET}_{\mathrm{A}}$ receptor), and BQ788 (a selective peptide antagonist for the $\mathrm{ET}_{\mathrm{B}}$ receptor). To clarify if the $\mathrm{ET}_{\mathrm{B}}$ receptors in HASMCs were involved in ET-1- induced activation of ERK1/2, sarafotoxin 6c (S6c), a selective $\mathrm{ET}_{\mathrm{B}}$ receptor agonist was employed and the phosphorylation of ERK1/2 was examined by immunofluorescence and western blot (Figure 2B and $2 \mathrm{~A}$ ). In figure $2 \mathrm{~B}$, there was a slight elevation of phosphorylated ERK1/2 (1.3 fold, $p<0.001)$ as observed at 5 min after exposure to $1 \mu \mathrm{M}$ of S6c. This peaked at $10 \mathrm{~min}$ ( 1.5 fold, $\mathrm{p}<0.001)$, and quickly declined at $15 \mathrm{~min}$ (1.3 fold, $\mathrm{p}<0.001$ ). This slight transient increase of phosphorylated ERK1/2 was also produced by $100 \mathrm{nM}$ of S6c and verified by western blot for pERK1/2 (Figure 2A). BQ123 and bosentan significantly inhibited the increase in pERK1/2 activities, while the $\mathrm{ET}_{\mathrm{B}}$ receptor antagonist BQ788 had no significant effect (Figure 2C and 2D). The increase in phosphorylated ERK1/2 was significantly inhibited by $5 \mu \mathrm{M}$ of BQ123 (by $51.8 \%$, Figure 2C), which is consistent with the results of phosphoELISA assay (by $51.9 \%$, Figure 2D) and western blot (by 56.2\%) [see Additional file 1]. ET-1-induced ERK1/2 activation was also significantly inhibited by combination of BQ123 and BQ788 by $65.4 \%$ (Figure 2C in immunocytochemistry), by $43.6 \%$ (Figure 2D in phophoELISA assay) and by $62.1 \%$ [see Additional file 1 in western blot]. Compared 
A
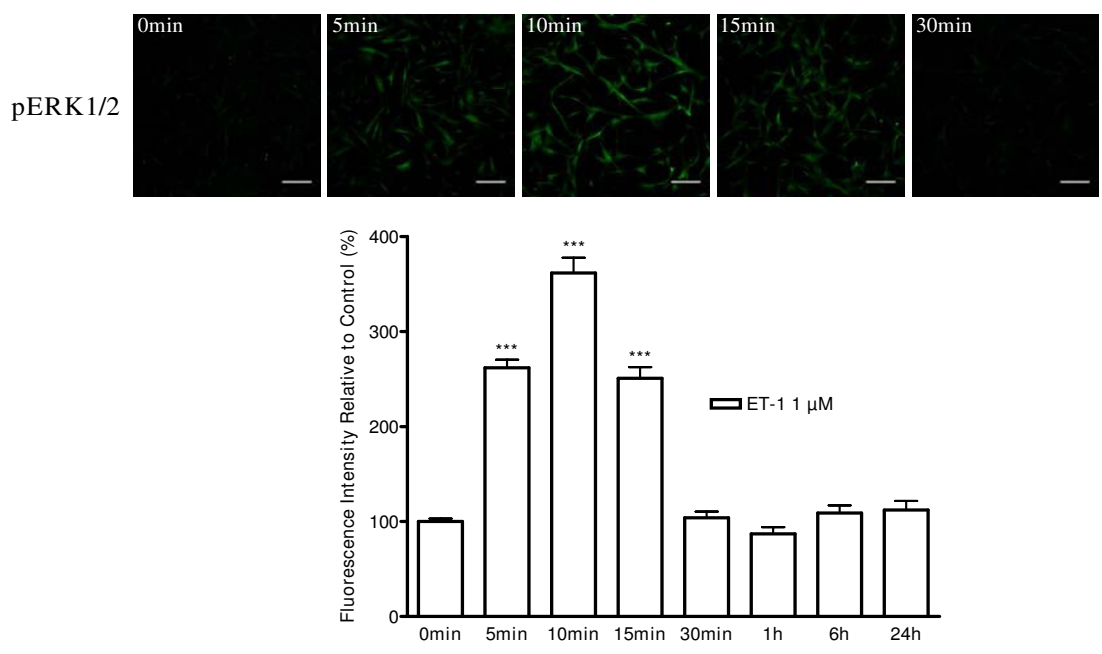

B

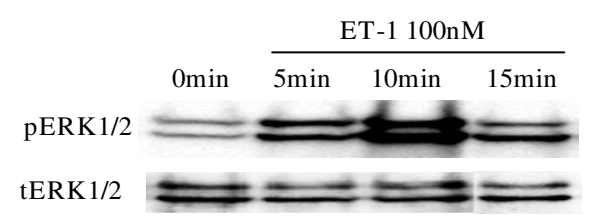

C
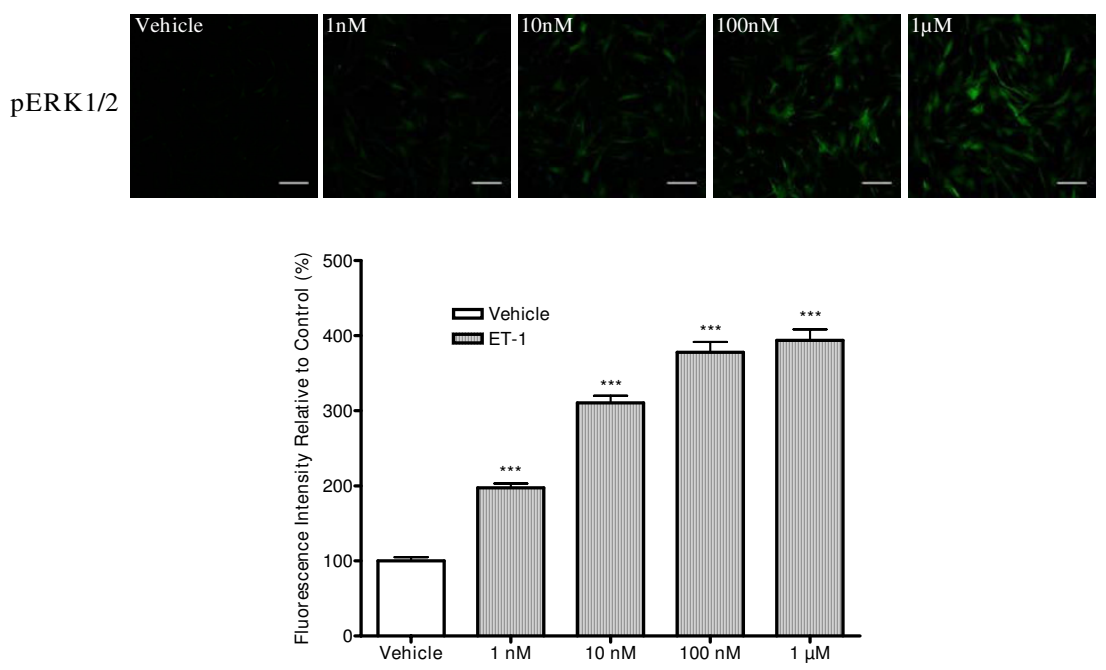

Figure I

Time course and concentration-effects of ET-I on activation of ERKI/2. Cultured HASMCs were starved for $24 \mathrm{~h}$ in serum-free medium and then stimulated with ET-I. A, bar graph shows time-dependent activation of ERKI/2 by ET-I at I $\mu$ M. Phosphorylated ERKI/2 was determined by immunofluorescence with an anti-phospho-ERKI/2 antibody. B, representative autoradiograph of western blot showing the level of phosphorylated and total ERKI/2 from the samples treated with ET-I at 0 $\mathrm{min}, 5 \mathrm{~min}, \mathrm{I} 0 \mathrm{~min}$ and $\mathrm{I} 5 \mathrm{~min}$. C, Bar graph shows concentration-dependent activation of ERKI/2 by ET-I from I nM to I $\mu M$ for $10 \mathrm{~min}$. Phosphorylated ERKI/2 was determined by immunofluorescence with an anti-phospho-ERKI/2 antibody. The upper panels of $A$ and $C$ indicate representative images of immunofluorescence showing the phosphorylated ERKI/2 from the samples treated with ET-I at different time points and various concentrations, respectively. The scale bar in each image represents $20 \mu \mathrm{m}$. Data represent mean \pm S.E.M. $* * * ~ p<0.001$ compared with the vehicle value. $p=$ phosphorylated; $t=$ total. 
A

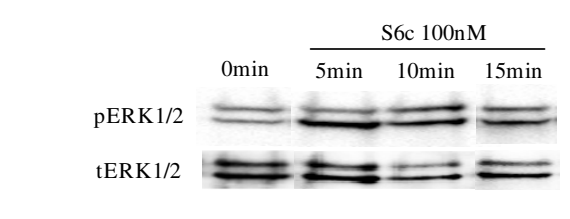

B
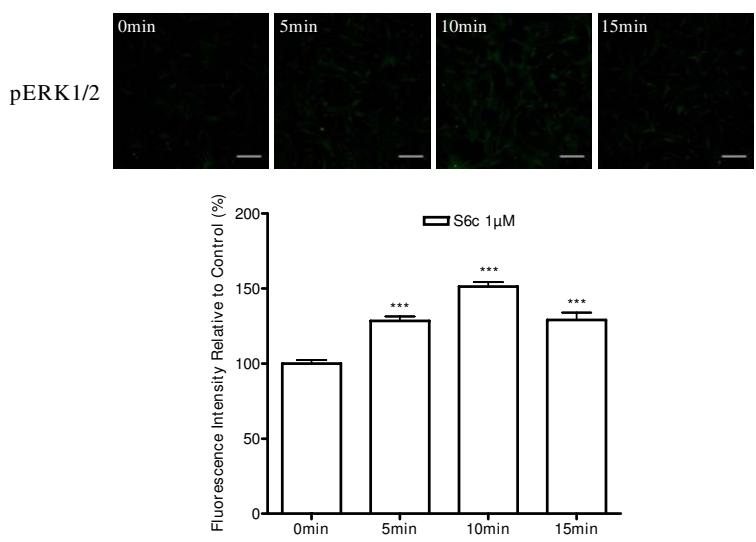

C
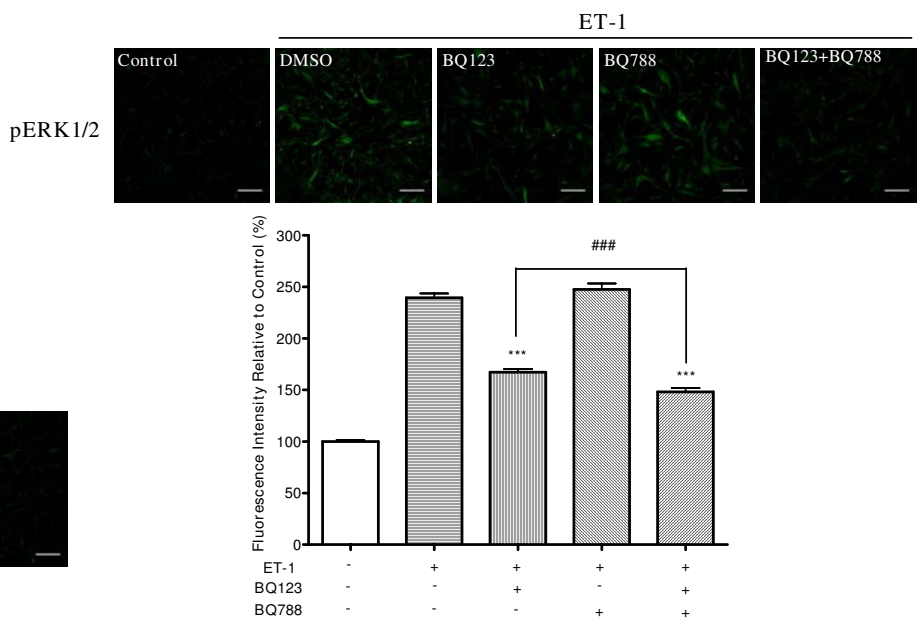

$\mathrm{D}$

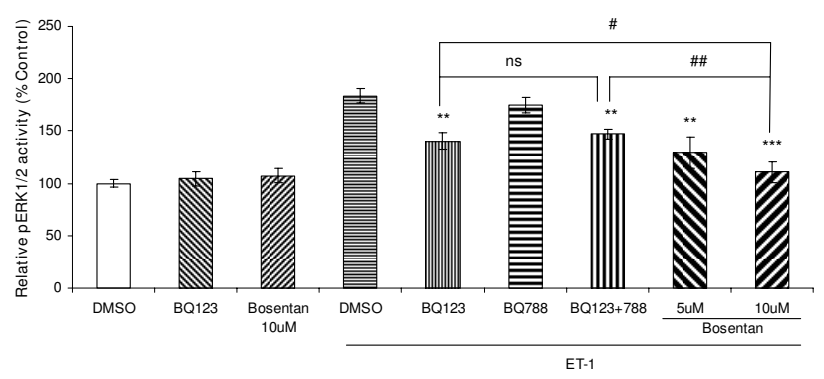

Figure 2

Roles of endothelin receptor subtypes in mediating ET-I-induced activation of ERKI/2 in HASMCs. Serumstarved cells were stimulated with S6c for 5,10 or 15 min or ET-I for 10 min. $5 \mu$ M of BQI23, $5 \mu$ M of BQ788, $5 \mu$ or $10 \mu M$ of bosentan were given for $30 \mathrm{~min}$ before addition of ET-I. A, representative autoradiograph of western blot showing the phosphorylated ERKI/2 and total ERKI/2 from samples treated with $100 \mathrm{nM}$ of $\mathrm{S} 6 \mathrm{c}$ at different time points. B, bar graph shows time-dependent activation of ERKI/2 by I $\mu$ M of S6c. Phosphorylated ERKI/2 was determined by immunofluorescence with an anti-phospho-ERKI/2 antibody. C, bar graph shows inhibitory effects of ET receptor inhibitors on phosphorylated ERKI/2 induced by $10 \mathrm{nM}$ of ET-I. Phosphorylated ERKI/2 was determined by immunofluorescence with an anti-phospho-ERKI/2 antibody. D, inhibitory effects of ET receptor inhibitors on phosphorylated ERKI/2 activity induced by $10 \mathrm{nM}$ of ET-I. Phosphorylated ERKI/2 activity was determined by phosphoELISA assay as described in Methods. The upper panels of $B$ and $C$ indicate representative images of immunofluorescence showing the phosphorylated ERKI/2 from samples treated with S6c at different time points and treated with ET receptor inhibitors prior to addition of ET-I, respectively. The scale bar in each image represents $20 \mu \mathrm{m}$. Data represent mean \pm S.E.M. *** $p<0.00$ I compared with the vehicle value (B). $* * p<0.01$, $* * * p<0.001$ compared with the ET-I-stimulated states after DMSO treatment (C,D). \# p < 0.05, \#\# p <0.0I, \#\# p < $0.00 \mathrm{I} ; \mathrm{p}=$ phosphorylated; $\mathrm{t}=$ total, $\mathrm{ns}=$ non-significant.

to BQ123, a further inhibitory effect was seen in combination of BQ123 and BQ788 ( $<0.001$, Figure 2 C). Bosen$\tan$ at $5 \mu \mathrm{M}$ and $10 \mu \mathrm{M}$ significantly inhibited ET-1induced activation of ERK $1 / 2$ by $65.1 \%$ and $87.1 \%$, respectively (Figure 2D). At $10 \mu \mathrm{M}$ bosentan had a stronger inhibitory effect on ET-1-induced activation of ERK1/2 than either BQ123 or combination of BQ123 and BQ788 ( $<<0.05$, or $\mathrm{p}<0.01$, Figure 2D). This indicated that $\mathrm{ET}_{\mathrm{B}}$ receptor antagonist $\mathrm{BQ788}$ had no significant inhibitory effect on ET-1-induced activation of ERK1/2 in the absence of $\mathrm{ET}_{\mathrm{A}}$ receptor antagonist $\mathrm{BQ} 123$, while bosentan, a dual ET receptor agonist or combined use of BQ123 and BQ788, further decreased ET-1-induced activation of ERK1/2.

\section{Role of the MEK on ET-I-induced activation of ERKI/2}

Three different MEK/ERK kinase inhibitors were used to study ET-1-induced activation of ERK1/2 in HASMCs. As shown in Figure 3A and 3B, U0126, a potent MEK1/2 inhibitor, at the concentration 1 and $10 \mu \mathrm{M}$ completely 
inhibited ET-1-induced phosphorylation of ERK1/2 from $258 \%$ to $87 \%$ and $63 \%$, respectively. SL327, another selective inhibitor of MEK1 and MEK2 had similar degree of inhibitory effects (Figure 3A). PD98059, a selective inhibitor of MEK1, only partially inhibited ET-1-induced phosphorylation of ERK1/2 from $258 \%$ to $153 \%$ at $1 \mu \mathrm{M}$, and to $145 \%$ at $10 \mu \mathrm{M}$, respectively (Figure $3 \mathrm{~A}$ ). This suggests that both MEK1 and MEK2 are required for ET-1 to activate ERK1/2 in HASMCs. This is further supported by phosphoELISA assay (Figure 3B) and western blot [see Additional file 1]. Compared to PD98059, U0126 at $1 \mu \mathrm{M}$ had a significant stronger inhibitory effect $(\mathrm{p}<0.001$, Figure 3A). To clarify whether U0126 also inhibits phosphorylation of ERK1/2 in untreated control cells, the phosphoELISA assay was used. It showed that in untreated control HASMCs, U0126 at $1 \mu \mathrm{M}$ did not signif-

A
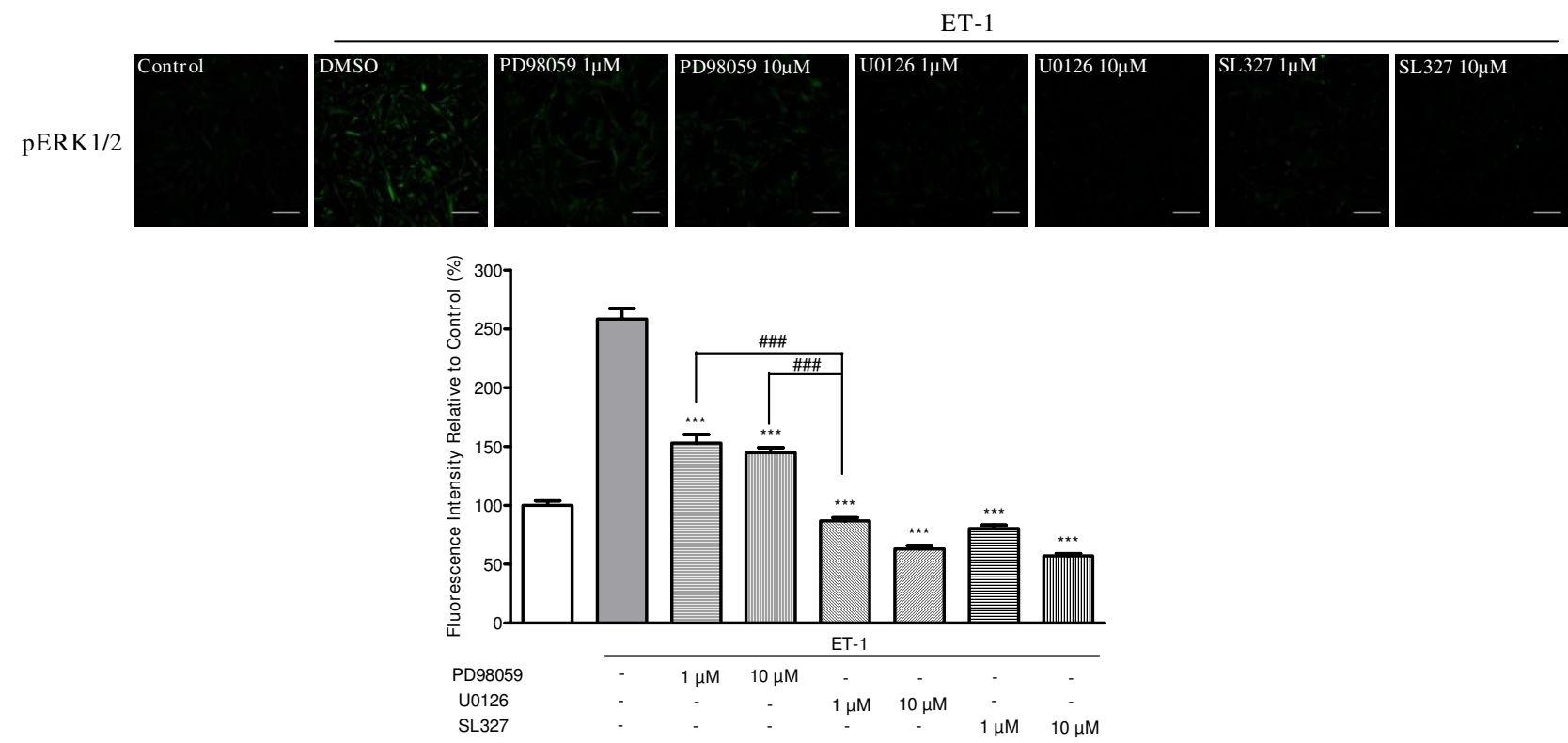

B

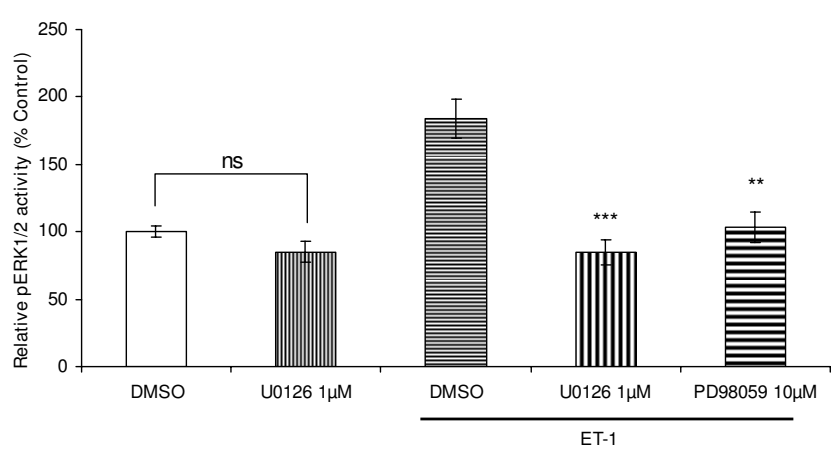

Figure 3

Effects of MEK inhibitors on ET-I-induced activation of ERKI/2 in HASMCs. Serum-starved cells were treated with U0I26, PD98059 or SL327 for 30 min prior to addition of ET-I. A, bar graph shows inhibitory effects of MEK inhibitors on phosphorylated ERKI/2 induced by $10 \mathrm{nM}$ of ET-I. Phosphorylated ERK I/2 was determined by immunofluorescence with an anti-phospho-ERKI/2 antibody. B, inhibitory effects of MEK inhibitors on phosphorylated ERKI/2 activity induced by $10 \mathrm{nM}$ of ET-I. Phosphorylated ERKI/2 activity was determined by phosphoELISA assay as described in Methods. The upper panel of $A$ indicates representative images of immunofluorescence showing the phosphorylated ERKI/2 from the samples treated with MEK inhibitors prior to addition of ET-I. The scale bar in each image represents $20 \mu \mathrm{m}$. Data represent mean \pm S.E.M. ** $p<$ 0.01 , *** $p<0.00$ I compared with the ET-I-stimulated states after DMSO treatment. \#\# $p<0.00 \mathrm{I} ; \mathrm{p}=\mathrm{phosphorylation,} \mathrm{ns}$ = non-significant. 
icantly modify ERK1/2 activity (Figure 3B). In ET-1treated HASMCs, U0126 significantly decreased the phosphorylated ERK1/2 level at the same concentration (Figure $3 \mathrm{~A}$ and $3 \mathrm{~B}$ ).

\section{Roles of PKCIPKA and small G proteins on ET-I-induced activation of ERKI/2}

To further determine the upstream signaling involved in the MEK/ERK pathway, we used pharmacological inhibitors and examined the effects of PKC inhibitors (staurosporin and GF109203X), PKC-delta inhibitor (Rottlerin), PKA specific inhibitor (H-89), and PI3K inhibitor (wortmannin) on ET-1-induced pERK1/2 activities (Figure 4). The activation of ERK1/2 was significantly inhibited by $500 \mathrm{nM}$ of staurosporin $(93.2 \%), 10 \mu \mathrm{M}$ of GF 109203X (89.1\%), $5 \mu \mathrm{M}$ of Rottlerin (58.4\%), $10 \mu \mathrm{M}$ of H-89 (83.8\%), and $2 \mu \mathrm{M}$ of Wortmannin (91.6\%), respectively (Figure 4A). Similar, results were obtained in the phosphoELISA assay (Figure 4B).

\section{Role of extracellular $\mathrm{Ca}^{2+}$ influx or intracellular $\mathrm{Ca}^{2+}$ release in mediating $E T$ - I-induced activation of $E R K I / 2$ in HASMCs}

$\mathrm{Ca}^{2+}$, a second messenger, has a central role in activation of various key cellular responses, including muscle contraction, cell proliferation, migration and adhesion [20]. To evaluate the role of intracellular $\mathrm{Ca}^{2+}$ signaling in mediating ET-1-induced activation of ERK1/2, nifedipine was used to block external $\mathrm{Ca}^{2+}$ influx through L-type $\mathrm{Ca}^{2+}$ channels, $5 \mathrm{mM}$ of EGTA was employed to chelate extracellular $\mathrm{Ca}^{2+}$, and $1 \mu \mathrm{M}$ of thapsigargin was used to cause intracellular $\mathrm{Ca}^{2+}$ stores to become depleted. KN-62, a calcium-calmodulin dependent protein kinase II (CAMKII) inhibitor was also examined (Figure 5). The activation of ERK1/2 was not affected by L-type $\mathrm{Ca}^{2+}$ channel blocker (Figure 5A), chelating extracellular $\mathrm{Ca}^{2+}$ (Figure 5C), abolishing intracellular $\mathrm{Ca}^{2+}$ release (Figure 5D), or inhibition of CAMKII (Figure 5B). Replacing the medium with calcium-free PBS [see Additional file 2] did not inhibit ET-1induced activation of ERK1/2. These indicated that extracellular $\mathrm{Ca}^{2+}$ influx and $\mathrm{Ca}^{2+}$ released from internal stores were not necessarily required for the ET-1-induced phosphorylation of ERK1/2 in HASMCs. This is further supported by the results from phosphoELISA assay (Figure $5 \mathrm{E})$. To identify whether extracellular $\mathrm{Ca}^{2+}$ was chelated or $\mathrm{Ca}^{2+}$ influx was decreased in our experiments, we used 1 $\mu \mathrm{M}$ of thapsigargin to induce extracellular $\mathrm{Ca}^{2+}$ influx through store-operated $\mathrm{Ca}^{2+}$ channels (SOCC) [21]. We found that thapsigargin resulted in an activation of ERK1/ 2 in HASMCs as reported in RBL-1 cells [21]. The activation of ERK1/2 was abolished by $5 \mathrm{mM}$ of EGTA [see Additional file 3]. This suggests that $5 \mathrm{mM}$ of EGTA can effectively chelate extracellular $\mathrm{Ca}^{2+}$ and decrease $\mathrm{Ca}^{2+}$ influx in our experiments.

\section{Discussion}

The present study has revealed that ET- 1 acts primarily via the $\mathrm{ET}_{\mathrm{A}}$ receptors to induce phosphorylation of ERK1/2 in HASMCs. The ET-1-induced response requires intracellular signal molecule PKC, PKA and PI3K activities, while it is independent of intracellular calcium signaling.

\section{ET- I-induced activation of ERKI/2 in HASMCs}

ERK1/2 are important regulators of cell proliferation and migration in VSMCs $[8,9]$. These basic cellular functions are important for the formation of the neointima in pathologic states such as atherosclerosis. Many stimuli such as mechanical stretch, growth factors, cytokines and activation of G protein-coupled receptors, can result in phosphorylation of ERK1/2 and its signal pathways. Recent studies have demonstrated that ERK1/2 MAPK pathways regulate $\mathrm{Ca}^{2+}$-dependent and $\mathrm{Ca}^{2+}$-independent contraction of VSMCs [10-12,19]. Intracellular ERK1/2 MAPK signal mechanisms play important roles in vascular pathology and in the development of cardiovascular disease [22-24]. ET-1 not only remains the most potent and long-lasting vasoconstrictor of human vessels, it also induces proliferation of vascular smooth muscle cells through activation of ERK1/2 [25] in pulmonary hypertension, atherosclerosis, heart failure and restenosis $[2,26]$. In human arterial smooth muscle cells, ET-1induced activation of ERK1/2 is much weaker in aortic artery than in coronary artery [27]. This implies that small arteries are more sensitive than large arteries. Unlike angiotensin II, which shows a rapid and transient increase in activities of ERK1/2 [14], ET-1 induced a long-lasting phosphorylation of ERK1/2 with a peaked at $10 \mathrm{~min}$ and declined to baseline after $30 \mathrm{~min}$ in present study. The activation of ERK1/2 by ET-1 might contribute to VSMC proliferation in formation of new intima and thus it may contribute to serve as an early "switch-on" mechanism for cardiovascular disease development [28].

Roles of ET receptors in activation of ERKI/2 in HASMCs The physiological and pathological effects of ET-1 are mediated through two $G$ protein-coupled receptors, $\mathrm{ET}_{\mathrm{A}}$ and $\mathrm{ET}_{\mathrm{B}}$. In human vasculature, $\mathrm{ET}_{\mathrm{A}}$ receptors predominate on the smooth muscle cells and mediate constriction, whereas $\mathrm{ET}_{\mathrm{B}}$ receptors are expressed less than $15 \%$ on these cells $[29,30]$. In-vivo studies suggest that both subtypes of endothelin receptors can mediate vasoconstriction in human resistance and capacitance vessels [31]. In the present study, we found that $\mathrm{ET}_{\mathrm{A}}$ predominately mediated ET-1-induced activation of ERK1/2. Although some activation of ERK1/2 was obtained with the $\mathrm{ET}_{B}$-selective agonist, S6c, the maximum response produced to S6c was transient and less than $20 \%$ of the ET- 1 effect. In addition, $\mathrm{BQ} 123$, a selective antagonist of the $\mathrm{ET}_{\mathrm{A}}$ receptor [32], but not $\mathrm{ET}_{\mathrm{B}}$ receptor antagonist $\mathrm{BQ788}$, significantly inhibited the activation of ERK1/2 induced by ET-1, suggesting that 
A
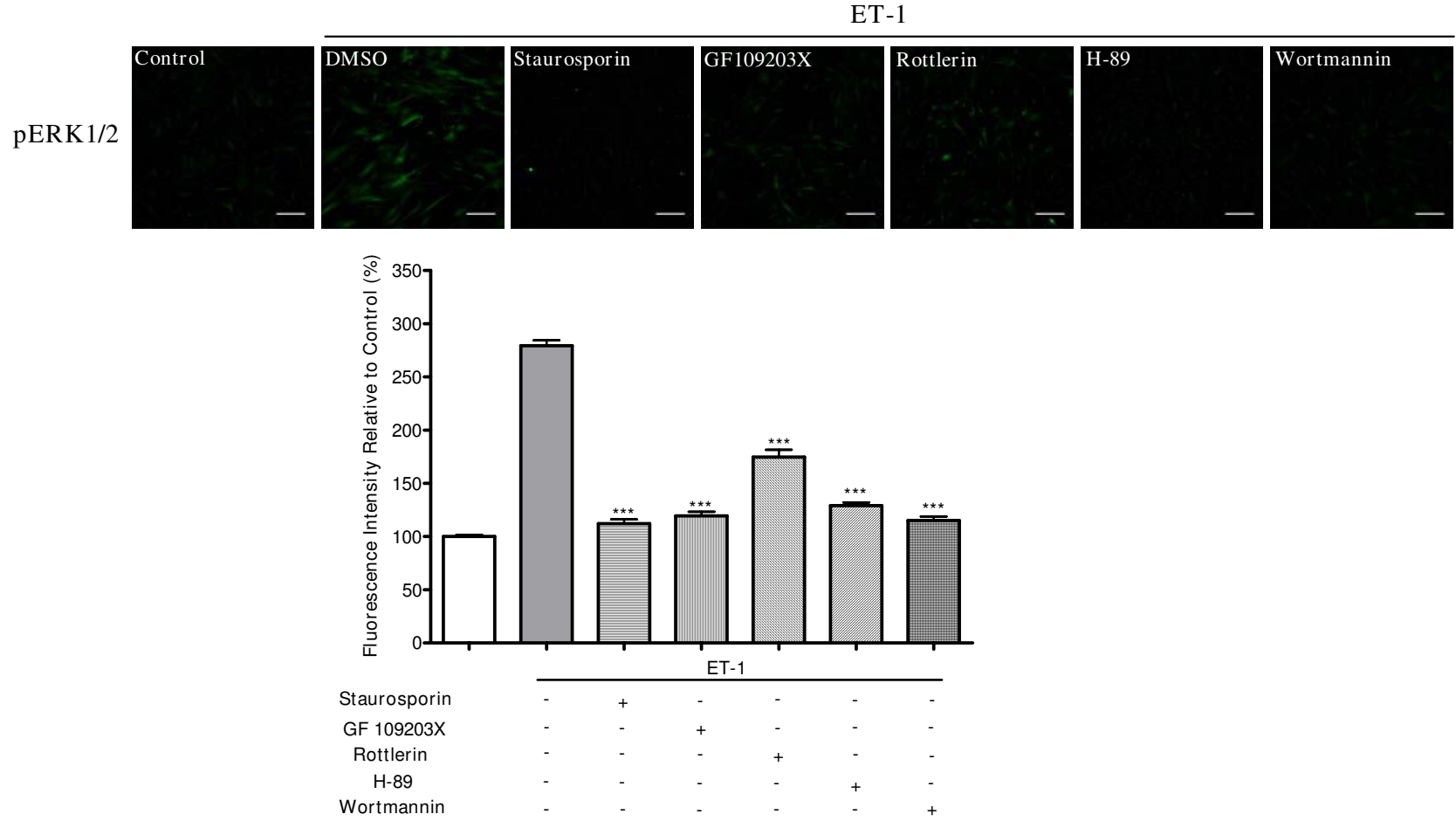

B

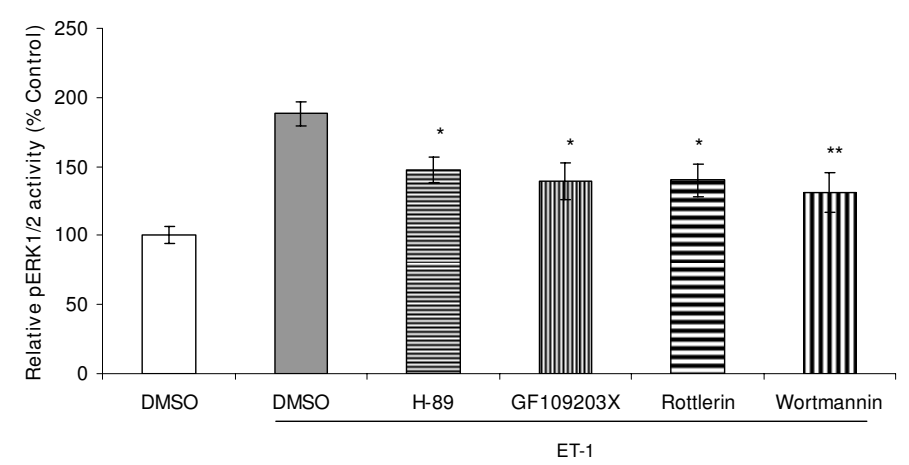

\section{Figure 4}

Effects of PKC, PKA and PI3 kinase inhibitors on ET-I-induced activation of ERKI/2 in HASMCs. Serum-starved cells were treated with $500 \mathrm{nM}$ of staurosporin, $10 \mu \mathrm{M}$ of GFI09203X, $5 \mu \mathrm{M}$ of rottlerin, $10 \mu \mathrm{M}$ of $\mathrm{H}-89$, or $2 \mu \mathrm{M}$ of wortmannin for 30 min prior to addition of ET-I. A, bar graph shows inhibitory effects of inhibitors on phosphorylated ERKI/2 induced by $10 \mathrm{nM}$ of ET-I. Phosphorylated ERKI/2 was determined by immunofluorescence with an anti-phospho-ERKI/2 antibody. B, inhibitory effects of inhibitors on phosphorylated ERKI/2 activity induced by $10 \mathrm{nM}$ of ET-I. Phosphorylated ERKI/2 activity was determined by phosphoELISA assay as described in Methods. The upper panel of A indicates representative images of immunofluorescence showing the phosphorylated ERKI/2 from samples treated with inhibitors prior to addition of ET-I. The scale bar in each image represents $20 \mu \mathrm{m}$. Data represent mean \pm S.E.M. ${ }^{*} p<0.05$, **p $<0.01$, *** $p<0.001$ compared with the ET-I-stimulated states after DMSO treatment. $\mathrm{p}=$ phosphorylation. 
A

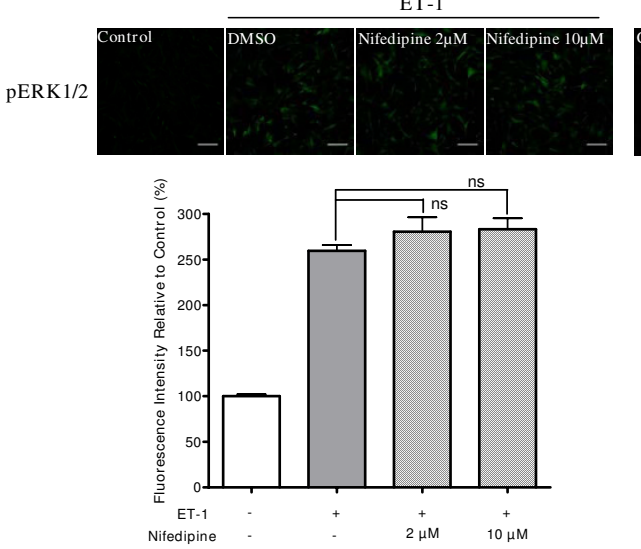

$\mathrm{D}$
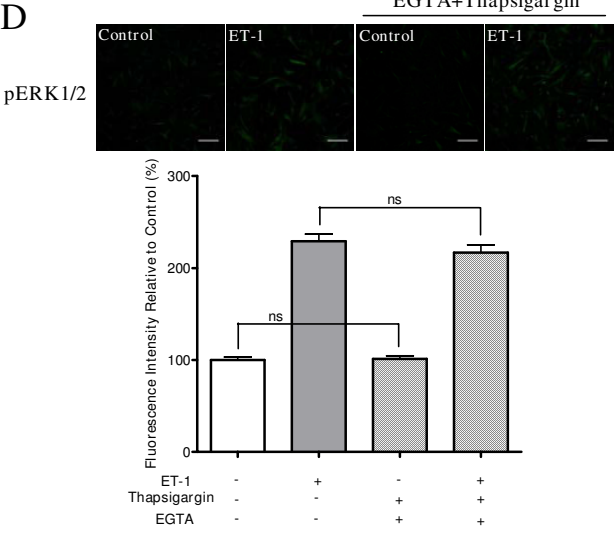

B
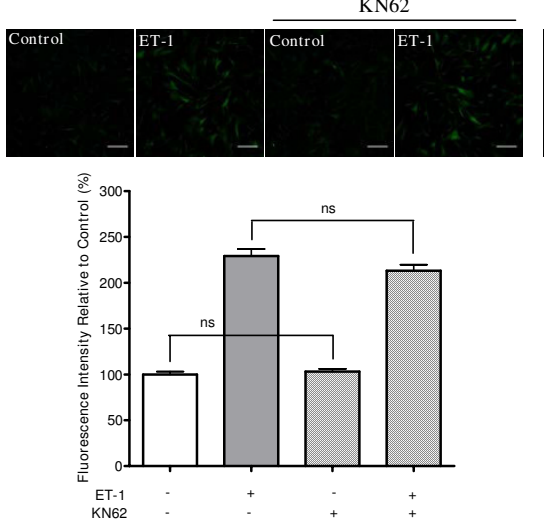

$\mathrm{E}$

E

Figure 5
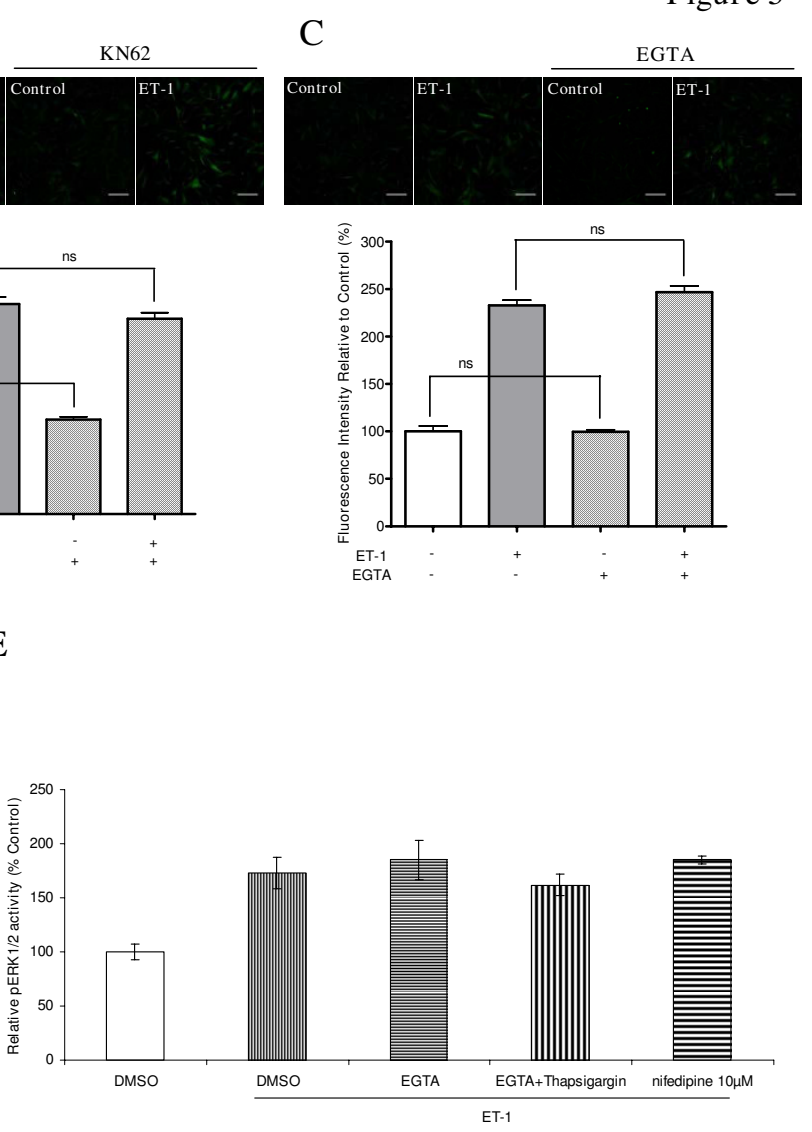

\section{Figure 5}

Role of intracellular $\mathrm{Ca}^{2+}$ in mediating ET-I-induced activation of ERKI/2 in HASMCs. Serum-starved cells were treated with $10 \mathrm{nM}$ of ET-I for 10 min after different treatments. A, L-type $\mathrm{Ca}^{2+}$ channel inhibitor nifedipine was treated for 30 min before addition of ET-I, bar graph shows effects of nifedipine at $2 \mu \mathrm{M}$ and $10 \mu \mathrm{M}$ on phosphorylated ERKI/2 induced by ET-I. Phosphorylated ERKI/2 was determined by immunofluorescence with an anti-phospho-ERKI/2 antibody. B, I0 $\mu$ M of KN-62 was given for 30 min before addition of ET-I, bar graph shows effect of KN-62 on phosphorylated ERKI/2 induced by ET-I. C, $5 \mathrm{mM}$ of the $\mathrm{Ca}^{2+}$ chelator EGTA was administered I 5 min before addition of ET-I, bar graph shows effect of EGTA on phosphorylated ERKI/2 induced by ET-I. D, the cells were treated with I $\mu$ M of thapsigargin with 5 mM of EGTA for I5 min before addition of ET-I, bar graph shows effect of thapsigargin on phosphorylated ERKI/2 induced by ET-I in the presence of EGTA. E, the treatment of cells with $10 \mu \mathrm{M}$ of nifedipine, $5 \mathrm{mM}$ of EGTA, or I $\mu \mathrm{M}$ of thapsigargin with $5 \mathrm{mM}$ of EGTA before addition of ET-I, bar graph shows effects of the different treatments on phosphorylated ERKI/2 activity induced by ETI as determined by the phosphoELISA assay. The upper panels of $A, B, C$ and $D$ indicate representative images of immunofluorescence illustrating the phosphorylated ERKI/2 from samples given the different treatments prior to addition of ET-I. The scale bar in each image represents $20 \mu \mathrm{m}$. Data represent mean \pm S.E.M. ns = non-significant. $\mathrm{p}=$ phosphorylation.

ET-1-induced activation of ERK1/2 is predominately mediated by $\mathrm{ET}_{\mathrm{A}}$ receptors. Compared to BQ123, a further inhibition of ET-1-induced activation of ERK1/2 was obtained in combination of BQ123 and BQ788. Bosentan, a dual $\mathrm{ET}_{\mathrm{A}}$ and $\mathrm{ET}_{\mathrm{B}}$ receptor antagonist had a significant stronger inhibitory effect on ET-1-induced activation of ERK1/2 than either BQ123 or the combination of BQ123 and BQ788. These results suggest that ET receptor dimerization [33] might also occur in human VSMCs in the presence of ET-1 as a bivalent ligand connecting two receptors [34-36] and that the receptor cross-talk is involved in the ET-1 effect. However, this requires more studies to verify.

\section{Upstream intracellular signal molecules involved in ET-I-} induced activation of ERKI/2

ERK1/2 activation requires a sequential activation of Ras, Raf and MEK signal cascades [14,37]. MEK inhibitors (U0126, PD98059 and SL327) were used to investigate the role of upstream MEK in ET-1-induced activation of 
ERK1/2. U0126, a highly selective inhibitor of MEK1/2 had the same potency as SL327 (another selective inhibitor of MEK1/2), and completely inhibited ET-1-induced activation of ERK1/2, whereas, PD98059, a selective MEK1 inhibitor, only partially inhibited ET-1-induced activation of ERK1/2. PKC, a family of serine/threonine kinases, may be involved in the intracellular signal transduction of MEK/ERK1/2 induced by ET-1. PKA is an important second messenger. Cyclic AMP-independent activation of PKA by ET- 1 has been observed in rat aortic smooth muscle cells [38]. On the other hand, G-proteincoupled receptor signaling can be mediated through various small G proteins. The Ras/Raf pathway is found to be a proximal regulator of MEK [14,39]. PI3K, another downstream effector of Ras [40], has been linked to a diverse group of cellular functions, including cell growth, proliferation, differentiation, motility, survival [41]. By using selective inhibitors, the present study revealed that PKC, PKA and PI3K were involved in activation of ERK1/ 2 induced by ET-1 in HASMCs, which may provide targets for drug discovery [42].

\section{Intracellular $\mathrm{Ca}^{2+}$ signaling was not required for ET-I- induced activation of ERKI/2}

ET-1 stimulates phospholipase C-dependent hydrolysis of $\mathrm{PIP}_{2}$ (phosphatidylinositol 4,5-bisphosphate) through Gprotein coupled receptors, leading to the generation of inositol 1,4,5-trisphosphate (IP3) and diacylglycerol (DAG), which are involved in intracellular $\mathrm{Ca}^{2+}$ mobilization and PKC activation [5]. Recently, growing evidence has shown that $\mathrm{Ca}^{2+}$ signaling is critical for activation of ERK1/2 induced by angiotensin II in VSMCs [15-17]. However, the role of intracellular $\mathrm{Ca}^{2+}$ signaling in ET-1induced activation of ERK1/2 in human VSMCs remains unclear. It has been reported that the activation of L-type $\mathrm{Ca}^{2+}$ channels contributes to ET-1-induced sustained phase of the $\mathrm{Ca}^{2+}$ response and the ability to generate force [43]. Unlike angiotensin II, the present study revealed that extracellular $\mathrm{Ca}^{2+}$ influx through L-type $\mathrm{Ca}^{2+}$ channels did not participate in ET-1-induced activation of ERK1/2 in human VSMCs. To further investigate the involvement of intracellular $\mathrm{Ca}^{2+}$ through other $\mathrm{Ca}^{2+}$ channels, which are suggested to be involved in ET-1mediated contractions of VSMC [43] and mitogenesis [44], $5 \mathrm{mM}$ of EGTA was used. Extracellular $\mathrm{Ca}^{2+}$ chelation by EGTA did not affect activation of ERK1/2 induced by ET-1. ET-1-induced $\mathrm{Ca}^{2+}$ release from intracellular stores is triggered by the binding of IP3 to receptors on the sarcoplasmic reticulum (SR). Depletion of intracellular $\mathrm{Ca}^{2+}$ stores can lead to a local $\mathrm{Ca}^{2+}$ flux through store-operated $\mathrm{Ca}^{2+}$ channels (SOCC), which has been reported to initiate the activation of ERK1/2 in RBL-1 cells [21]. Therefore, in our studies, thapsigargin, an inhibitor to the SR $\mathrm{Ca}^{2+}$ ATPase pump, which results in $\mathrm{Ca}^{2+}$ release and depletion from internal stores, was applied together with $5 \mathrm{mM}$ of EGTA. The results showed that ERK1/2 activation by ET-1 did not require the participation of intracellular $\mathrm{Ca}^{2+}$ release. Studies have indicated that the CAMKII pathway mediates G-protein coupled receptor ligand-depedent activation of ERK1/2 in cultured VSM cells $[36,45,46]$. However, we observed that CAMKII pathway was probably not involved in the ET-1- induced activation of ERK1/ 2 in human VSMCs as based on KN-62 inhibition experiment. Using receptor-operated $\mathrm{Ca}^{2+}$ channel blockers LOE 908 and SK\&F 96365, and L-type $\mathrm{Ca}^{2+}$ channels blocker nifedipine, Kawanabe et al noted that ET-1-induced ERK1/2 activiation involved a $\mathrm{Ca}^{2+}$ influx-dependent cascade through $\mathrm{Ca}^{2+}$ permeable nonselective cation channels (NSCCs) and SOCC, and a $\mathrm{Ca}^{2+}$ influx-independent cascade in rabbit carotid artery VSMCs [47]. The studies showed that maximal effective concentration of nifedipine has only $10 \%$ of the inhibition on ET-1-induced increases in ERK1/2 activity. However, we did not find significant changes of phosphorylated ERK1/2 induced by ET-1 after treatment with nifedipine or chelation of extracellular $\mathrm{Ca}^{2+}$.

\section{Conclusion}

In conclusion, we have demontrated that ET-1-induced activation of ERK1/2 in human VSMCs is predominantly mediated by $\mathrm{ET}_{\mathrm{A}}$ receptors through upstream signal molecule PKC, PKA and PI3K, while it is independent of CAM$\mathrm{KII}$ and intracellular $\mathrm{Ca}^{2+}$ signaling. The endothelin system plays key roles in hypertension, stoke and myocardial infarction. Understanding the intracellular signaling mechanisms of endothelin receptors may provide new strategies for developing new drugs for cardiovascular diseases.

\section{Methods \\ Reagents and antibodies}

ET-1 and S6c, a selective $\mathrm{ET}_{\mathrm{B}}$ receptor agonist [48], were used at different concentration to stimulate phosphorylation (activation) of ERK1/2 in human VSMCs. To detect the intracellular signal pathways involved in activation of ERK1/2, a set of inhibitors were administered prior to addition of stimulators. Bosentan, a dual endothelin receptor antagonist was purchased from SynFine Research (Ontario, Canada). $\mathrm{ET}_{\mathrm{A}}$ antagonist $\mathrm{BQ} 123$ and $\mathrm{ET}_{\mathrm{B}}$ antagonist BQ788 $[4,48]$ were employed to examine the mediation of endothelin receptors in activation of ERK1/2. PD98059, a MEK1 inhibitor, and U0126, SL327, selective inhibitors of both MEK1 and MEK2, were used as ERK inhibitors. Staurosporin and GF109203X, PKC inhibitors; Rottlerin, a PKC-delta inhibitor; H-89, a PKA inhibitor; Wortmannin, a specific inhibitor of PI3K, were used as protein kinase inhibitors or phosphoinositide 3-kinase inhibitor. Nifedipine, a L-type $\mathrm{Ca}^{2+}$ channels inhibitor; EGTA (ethylene glycol tetraacetic acid), a $\mathrm{Ca}^{2+}$ chelator; thapsigargin, a sarco-endoplasmic reticulum $\mathrm{Ca}^{2+}$-ATPase pump inhibitor; KN-62, a CAMKII inhibitor, were applied to determine the involvement of $\mathrm{Ca}^{2+}$ signaling and CAM- 
KII in activation of ERK1/2. The concentration of inhibitors was determined by recommendation from product data sheet and literatures. All drugs were purchased from Sigma-Aldrich Co. (St. Louis, MO, USA). ET-1 and S6c were dissolved in sterile water with $0.1 \% \mathrm{BSA}$; the other reagents were dissolved in DMSO as a stock solution and diluted in cell culture medium before use.

A monoclonal antibody for phospho-ERK1/2 (phospho T183 + Y185) and a polyclonal antibody for total-ERK1/2 were obtained from Abcam plc. (Cambridge, UK). Polyclonal $\beta$-actin was purchased from Cell Signaling Technology, Inc. (Boston, MA, USA).

\section{Cell Culture and Experimental Protocol}

HASMCs at the end of the tertiary culture stage were obtained as a commercially available product from Cascade Biologics Inc. (Portland, OR, USA). Cells were plated in $75 \mathrm{~cm} 2$ tissue culture flasks at a density of $2.5 \times 103$ viable cells/cm2 in Medium 231 supplemented with 5\% smooth muscle growth supplement (SMGS). Medium 231 and SMGS were purchased from Cascade Biologics Inc. The cells were incubated in a $5 \% \mathrm{CO} 2$ incubator at $37^{\circ} \mathrm{C}$ and the medium was replaced every other day until the culture was approximately $80-90 \%$ confluent. Then the cells were removed from the flasks with accutaseTM Enzyme Cell Detachment Medium (eBioscience, Inc. San Diego, CA, USA) and seeded onto 100-mm tissue culture dish (Greiner Bio-One GmbH, Frickenhausen, Germany).

All experiments were performed with the cells of passages 6 to 9 . HASMCs were allowed to grow to $70 \%-80 \%$ confluence within 2 to 3 days, and maintained in medium 231 with $0.05 \%$ SMGS for $24 \mathrm{~h}$, then we added vehicle or ET-1, S6c at different concentration from $1 \mathrm{nM}$ to $1 \mathrm{uM}$, or with a time course at $5 \mathrm{~min}, 10 \mathrm{~min}, 15 \mathrm{~min}, 30 \mathrm{~min}, 1 \mathrm{~h}$, $6 \mathrm{~h}$ and $24 \mathrm{~h}$. Inhibitors or DMSO were treated for $30 \mathrm{~min}$ prior to addition of ET-1.

\section{Immunofluorescence Analysis to Detect phosphorylated ERKI/2}

HASMCs were seeded at a density of $5 \times 10^{3} /$ well in 4 well NUNC Lab-Tek II Chamber Slides for 3 days and were starved in medium 231 with $0.05 \%$ SMGS for $24 \mathrm{~h}$. The cells were stimulated with ET- 1 or S6c at above indicated time points after treatment with vehicle or inhibitors for 30 minutes, and then washed, fixed in $4 \%$ paraformaldehyde, permeabilized in PBS containing 4\% Triton X-100. The monoclonal primary antibody against phosphoERK1/2 (phospho T183 + Y185) was added to the cells at 1: 1000 dilution and incubated at room temperature for 1 h or overnight at $4{ }^{\circ} \mathrm{C}$, followed by adding fluorescein isothiocynate (FITC)-conjugated goat anti-mouse secondary antibody at 1:5000 dilution in dark according to the recommendation of the manufacturer. In the control experiments, either the primary antibody or the secondary antibody was omitted. After washing with PBS, ProLong Gold antifade mounting reagent (Invitrogen Corporation, Carlsbad, CA, USA) was added and the cells were sealed with cover slip on the slide. The immunofluorescence stained cells were observed under a laser scanning confocal microscope (Nikon, C1plus, Nikon Instruments Inc., NY, USA) and analysed by ImageJ software http:// rsb.info.nih.gov/ii. The fluorescence intensity of cells was measured at 4 preset areas of per sample and at least three independent experiments were performed. The fluorescence intensity of each treated group was determined as the percent increase over control, with the control normalized to $100 \%$. There was no change of fluorescence intensity after cells were treated with inhibitors compared with vehicle treatment [see Additional file 4].

\section{Western Blot Analysis}

About $70 \%-80 \%$ confluent HASMCs in $100-\mathrm{mm}$ tissue culture dishes were made quiescent by placing them in medium 231 supplemented with $0.05 \%$ SMGS for $24 \mathrm{~h}$ and harvested in cell extract denaturing buffer (BioSource, USA) with addition of a phosphatase inhibitor cocktail and protease inhibitor cocktail (Sigma, USA) after treatment. Incubating cells at $4{ }^{\circ} \mathrm{C}$ for $30 \mathrm{~min}$, whole cell lysates were sonicated for $2 \mathrm{~min}$ on ice, centrifuged at $15,000 \times \mathrm{g}$ at $4^{\circ} \mathrm{C}$ for $30 \mathrm{~min}$, and the supernatants were collected as protein samples. The protein concentrations were determined using the protein assay reagents (BioRad, Hercules, CA, USA) and stored at $-80^{\circ} \mathrm{C}$ until immunoblotting assay. The protein homogenates were diluted $1: 1(\mathrm{v} / \mathrm{v})$ with $2 \times$ SDS sample buffer (Bio-Rad, USA). 2550 ug of total proteins were boiled for $10 \mathrm{~min}$ in SDS sample buffer and separated by 4-15\% SDS Ready Gel Precast Gels (Bio-Rad, USA) for $120 \mathrm{~min}$ at $100 \mathrm{v}$, and transferred electrophoretically to nitrocellulose membranes (BioRad, USA) at $100 \mathrm{v}$ for $60 \mathrm{~min}$. The membrane was then blocked for $1 \mathrm{~h}$ at room temperature with phosphate buffered saline (PBS) containing 0.1\% Tween-20 (Sigma, USA) and 5\% non-fat dried milk, and incubated with primary antibodies diluted 1:1000 overnight at $4{ }^{\circ} \mathrm{C}$, followed by incubation with ECL anti-mouse or anti-rabbit IgG, horseradish peroxidase-conjugated secondary antibodies (Amersham Biosciences, Piscataway, NJ, USA) diluted 1:10000 for $1 \mathrm{~h}$ at room temperature. The probed proteins were developed by LumiSensor Chemiluminescent HRP Substrate ECL Western Blot Detection Reagent (GenScript Corp., Piscataway, NJ, USA). To detect multiple signals using a single membrane, the membrane was incubated for 5-15 $\mathrm{min}$ at room temperature with restore plus western blot stripping buffer (Pierce Biotechnology, Inc., Rockford, IL. USA). The membranes were visualized using a Fujifilm LAS-1000 Luminiscent Image Analyzer (Stamford, CT, USA), and then quantification of band intensity was analyzed with Image Gauge Ver. 4.0 (Fuji Photo Film Co., LTD., Japan). Three independent experiments were performed in duplicate. 


\section{Cell-based PhosphoELISA Analysis}

HASMCs were seeded at a density of $3 \times 10^{3} /$ well in 96well plate for 3 days and starved in medium 231 with $0.05 \%$ SMGS for $24 \mathrm{~h}$. The cells were treated with vehicle or different inhibitors for $30 \mathrm{~min}$ prior to the addition of ET-1. After 10 min of ET-1 stimulation, the cells were fixed and stored at $4{ }^{\circ} \mathrm{C}$ until the performance of experiments. Phosphorylated ERK1/2 was measured using a cell-based ELISA Assay Kit (SABiosciences Corporation, MD, USA) following the manufacturer's instructions. Phosphorylated ERK1/2 activity was presented as a relative extent to the level of total ERK1/2. Independent experiments were done in duplicate or triplicate and were repeated at least three times.

\section{Statistical Analysis}

Comparison between two groups was performed using two-tailed unpaired Student's t-test with Welch's correction. For more than two groups one-way ANOVA followed by Dunnett's post test was used. A p-value, less than 0.05 was considered to be significant. Results were presented as mean \pm SEM. At least 3 different samples or independent experiments were analyzed in each group.

\section{Authors' contributions}

QC carried out the main part of the experiments, participated in the design, statistical analysis, drafting and writing of the manuscript. LE participated in the writing of the manuscript. CX conceived the study and the design, coordinated the work and the writing of the manuscript. All authors have read and approved the final manuscript.

\section{Additional material}

\section{Additional file 1}

Inhibitory effects of BQ123 and U0126 on pERK1/2 activity in HASMCs. The data provided represent the Western Blot analysis of inhibitory effects of $E T_{A}$ receptor inhibitor $B Q 123$ and MEK inhibitor U0126 on ET1-induced phosphorylation of ERK1/2. $24 \mathrm{~h}$ Serum-starved cells were stimulated with $10 \mathrm{nM}$ of ET-1 for $10 \mathrm{~min}$ after cells were treated with inhibitors for 30 min. Phosphorylated ERK1/2 activity was determined by western blot with an anti-phospho-ERK1/2 antibody, and presented as a relative extent to the level of $\beta$-actin. A, bar graph shows inhibitory effects of $5 \mu \mathrm{M}$ of $E T_{A} / E T_{B}$ receptor inhibitors on phosphorylated ERK1/2 activity induced by ET-1. B, bar graph shows inhibitory effect of $1 \mu \mathrm{M}$ of $U 0126$ on phosphorylated ERK1/2 activity induced by ET-1. The upper panels of $A$ and $B$ indicate representative autoradiographs of western blot showing phosphorylated ERK1/2 and $\beta$-actin. Data represent mean \pm S.E.M. ${ }^{*} p$ $<0.05, * * p<0.01$ compared with the ET-1-stimulated states after DMSO treatment. $p=$ phosphorylation, $n s=$ non-significant.

Click here for file

[http://www.biomedcentral.com/content/supplementary/14712121-10-52-S1.pdf]

\section{Additional file 2}

Effect of ET-1 on activation of ERK1/2 in HASMCs in the absence of external $\mathrm{Ca}^{2+}$. The data provided represent the immunofluorescence analysis of ET-1-induced phosphorylation of ERK1/2 in the absence of external $C a^{2+}$ by replacing culture medium with PBS. Serum-starved cells were placed in the presence or absence of external $\mathrm{Ca}^{2+}$ for 3 min by replacing culture medium with PBS plus $1 \mathrm{mM}$ EGTA prior to addition of ET-1. Phosphorylated ERK1/2 was determined at 10 min after the addition of $10 \mathrm{nM}$ of ET-1 by immunofluorescence with an anti-phospho-ERK1/2 antibody. The bar graph shows effect of ET-1 on phosphorylated ERK1/2 in the absence of extracellular $\mathrm{Ca}^{2+}$. The fluorescence intensities of phosphorylated ERK1/2 are expressed relative to the quiescent state in the presence of external $\mathrm{Ca}^{2+}$. The upper panel indicates representative images of immunofluorescence showing the phosphorylated ERK1/2 from samples given the different treatments. Data represent the mean \pm S.E.M. ${ }^{* * *} p$ $<0.001 . n s=$ non-significant.

Click here for file

[http://www.biomedcentral.com/content/supplementary/14712121-10-52-S2.pdf]

\section{Additional file 3}

The $\mathrm{Ca}^{2+}$ chelator EGTA abolished thapsigargin-induced activation of ERK1/2 in ET-1 untreated starved cells. The data provided represent the immunofluorescence analysis of inhibitory effect of the $\mathrm{Ca}^{2+}$ chelator EGTA on extracellular $\mathrm{Ca}^{2+}$ influx through thapsigargin-induced storeoperated $\mathrm{Ca}^{2+}$ channels. Serum-starved cells were treated with $1 \mu \mathrm{M}$ of thapsigargin with or without $5 \mu \mathrm{M}$ of EGTA for 15 min. Phosphorylated ERK1/2 was determined by immunofluorescence with an anti-phosphoERK1/2 antibody. The bar graph shows effect of thapsigargin on phosphorylated ERK1/2 in the presence or in the absence of EGTA. The upper panel indicates representative images of immunofluorescence showing the phosphorylated ERK1/2 from samples given the different treatments. Data represent mean \pm S.E.M. ${ }^{* * *} p<0.001$ compared with the vehicle value. Click here for file

[http://www.biomedcentral.com/content/supplementary/14712121-10-52-S3.pdf]

\section{Additional file 4}

Effects of the inhibitors used in the present study on the activities of ERK1/2 in ET-1 untreated cells. The data provided represent the immunofluorescence analysis of the stability of fluorescence intensity after cells were treated with inhibitors compared with vehicle treatment. Serum-starved cells were treated with variety of inhibitors indicated or DMSO for 30 min. Phosphorylated ERK1/2 was determined by immunofluorescence with an anti-phospho-ERK1/2 antibody. The bar graph shows no significant effects of the inhibitors on phosphorylated ERK1/2 in ET-1 untreated control cells. The upper panel indicates representative images of immunofluorescence showing the phosphorylated ERK1/2 from samples treated with different inhibitors. Data represent mean \pm S.E.M. Click here for file

[http://www.biomedcentral.com/content/supplementary/14712121-10-52-S4.pdf]

\section{Acknowledgements}

This study was supported by the Heart-Lung Foundation (grant no 20070273), Swedish Research Council (grant no 5958), Sweden, and the Flight Attendant Medical Research Institute (FAMRI, USA). 


\section{References}

I. Marasciulo FL, Montagnani M, Potenza MA: Endothelin-I: the yin and yang on vascular function. Curr Med Chem 2006, I3(14): I655-1665.

2. Schneider MP, Boesen El, Pollock DM: Contrasting actions of endothelin ET(A) and ET(B) receptors in cardiovascular disease. Annu Rev Pharmacol Toxicol 2007, 47:731-759.

3. Masaki T: Historical review: Endothelin. Trends Pharmacol Sci 2004, 25(4):21 9-224.

4. Adner M, Uddman E, Cardell LO, Edvinsson L: Regional variation in appearance of vascular contractile endothelin-B receptors following organ culture. Cardiovasc Res 1998, 37:254-262.

5. Cramer H, Schmenger K, Heinrich K, Horstmeyer A, Böning H, Breit A, Piiper A, Lundstrom K, Müller-Esterl W, Schroeder C: Coupling of endothelin receptors to the ERK/MAP kinase pathway. Roles of palmitoylation and G(alpha)q. Eur J Biochem 2001, 268(20):5449-5459.

6. Gohla A, Schultz G, Offermanns S: Role for $\mathbf{G ( I 2 ) / G ( 1 3 ) ~ i n ~ a g o - ~}$ nist-induced vascular smooth muscle cell contraction. Circ Res 2000, 87(3):221-227.

7. Pearson G, Robinson F, Beers Gibson T, Xu BE, Karandikar M, Berman K, Cobb MH: Mitogen-activated protein (MAP) kinase pathways: regulation and physiological functions. Endocr Rev 200I, 22(2): 153-183.

8. Liu B, Ryer EJ, Kundi R, Kamiya K, Itoh H, Faries PL, Sakakibara K, Kent KC: Protein kinase $C$-delta regulates migration and proliferation of vascular smooth muscle cells through the extracellular signal-regulated kinase I/2. J Vasc Surg 2007, 45(I): 160-168.

9. Zhan $Y$, Kim S, Izumi Y, Izumiya $Y$, Nakao T, Miyazaki H, Iwao H: Role of JNK, p38, and ERK in platelet-derived growth factorinduced vascular proliferation, migration, and gene expression. Arterioscler Thromb Vasc Biol 2003, 23(5):795-80I.

10. D'Angelo G, Adam LP: Inhibition of ERK attenuates force development by lowering myosin light chain phosphorylation. Am J Physiol Heart Circ Physiol 2002, 282(2):H602-H6IO.

II. Dessy C, Kim I, Sougnez CL, Laporte R, Morgan KG: A role for MAP kinase in differentiated smooth muscle contraction evoked by alpha-adrenoceptor stimulation. Am J Physiol 1998, 275(4 Pt I): CI08I-CI086.

12. Luo G, Jamali R, Cao YX, Edvinsson L, Xu CB: Vascular endothelin ET(B) receptor-mediated contraction requires phosphorylation of ERK I/2 proteins. Eur J Pharmacol 2006, 538(I-3): | 24- I 3 I.

13. Whitmarsh AJ, Davis RJ: Transcription factor AP-I regulation by mitogen-activated protein kinase signal transduction pathways. J Mol Med 1996, 74( I 0):589-607.

14. Yogi A, Callera GE, Montezano AC, Aranha AB, Tostes RC, Schiffrin EL, Touyz RM: Endothelin-I, but not Ang II, activates MAP kinases through c-Src independent Ras-Raf dependent pathways in vascular smooth muscle cells. Arterioscler Thromb Vasc Biol 2007, 27(9): 1960-1967.

15. Lucchesi PA, Bell JM, Willis LS, Byron KL, Corson MA, Berk BC: $\mathrm{Ca}(2+)$-dependent mitogen-activated protein kinase activation in spontaneously hypertensive rat vascular smooth muscle defines a hypertensive signal transduction phenotype. Circ Res 1996, 78(6):962-970.

16. Eguchi S, Matsumoto T, Motley ED, Utsunomiya H, Inagami T: Identification of an essential signaling cascade for mitogen-activated protein kinase activation by angiotensin II in cultured rat vascular smooth muscle cells. Possible requirement of Gq-mediated p2 I ras activation coupled to a $\mathbf{C a}^{2+} /$ calmodulin-sensitive tyrosine kinase. J Biol Chem 1996, 27|(24): |4|69-|4|75.

17. Eguchi S, Numaguchi K, Iwasaki H, Matsumoto T, Yamakawa T, Utsunomiya $\mathrm{H}$, Motley ED, Kawakatsu H, Owada KM, Hirata Y, Marumo F, Inagami T: Calcium-dependent epidermal growth factor receptor transactivation mediates the angiotensin IIinduced mitogen-activated protein kinase activation in vascular smooth muscle cells. J Biol Chem 1998, 273( I 5):8890-8896.

18. McNair LL, Salamanca DA, Khalil RA: Endothelin-I promotes $\mathrm{Ca}^{2+}$ antagonist-insensitive coronary smooth muscle contraction via activation of epsilon-protein kinase C. Hypertension 2004, 43(4):897-904.

19. Lee HM, Won KJ, Kim J, Park HJ, Kim HJ, Roh HY, Lee SH, Lee CK, Kim B: Endothelin-I induces contraction via a Syk-mediated p38 mitogen-activated protein kinase pathway in rat aortic smooth muscle. J Pharmacol Sci 2007, I03(4):427-433.

20. Berridge MJ, Bootman MD, Roderick HL: Calcium signalling: dynamics, homeostasis and remodelling. Nat Rev Mol Cell Biol 2003, 4(7):5 I7-529.

21. Chang WC, Di Capite J, Singaravelu K, Nelson C, Halse V, Parekh AB Local $\mathrm{Ca}^{2+}$ influx through $\mathrm{Ca}^{2+}$ release-activated (CRAC) channels stimulates production of an intracellular messenger and an intercellular pro-inflammatory signal. J Biol Chem 2008, 283(8):4622-463I.

22. Kim S, Iwao H: Molecular and cellular mechanisms of angiotensin II-mediated cardiovascular and renal diseases. Pharmacol Rev 2000, 52(I): I I-34

23. Lee KH, Lim S, Kang SM, Kim DH, Cho HK, Chung JH, Kwon HM, Chung $\mathrm{H}$, Lee $\mathrm{H}$, Jang $\mathrm{Y}$, Hwang $\mathrm{KC}$ : Antiproliferative mechanisms of raxofelast (IRFI-0 I 6) in $\mathrm{H2O2-stimulated} \mathrm{rat} \mathrm{aortic}$ smooth muscle cells. Eur J Pharmacol 2004, 484(2-3): I I9- I 25.

24. Cui MZ, Zhao G, Winokur AL, Laag E, Bydash JR, Penn MS, Chisolm $\mathrm{GM}, \mathrm{Xu} X$ : Lysophosphatidic acid induction of tissue factor expression in aortic smooth muscle cells. Arterioscler Thromb Vasc Bio 2003, 23(2):224-230.

25. Zeidan A, Broman J, Hellstrand P, Swärd K: Cholesterol dependence of vascular ERK I/2 activation and growth in response to stretch: role of endothelin- I. Arterioscler Thromb Vasc Biol 2003, 23(9): I 528-| 534

26. Lüscher TF, Barton M: Endothelins and endothelin receptor antagonists: therapeutic considerations for a novel class of cardiovascular drugs. Circulation 2000, I 02(I 9):2434-2340.

27. Yoshizumi M, Kim S, Kagami S, Hamaguchi A, Tsuchiya K, Houchi H, Iwao $H$, Kido $H$, Tamaki T: Effect of endothelin-I (I-3I) on extracellular signal-regulated kinase and proliferation of human coronary artery smooth muscle cells. $\mathrm{Br} J$ Pharmacol 1998, I 25(5): 1019-1027.

28. Hazzalin CA, Mahadevan LC: MAPK-regulated transcription: a continuously variable gene switch? Nat Rev Mol Cell Biol 2002, 3(1):30-40.

29. Davenport AP, O'Reilly G, Kuc RE: Endothelin ET $\mathbf{A}_{\mathbf{A}}$ and $\mathbf{E T}_{\mathbf{B}}$ mRNA and receptors are expressed by smooth muscle in the human vasculature: majority of the $\mathrm{ET}_{\mathbf{A}}$ subtype. $\mathrm{Br} J$ Pharmacol 1995, I |4(6): I I |0- I I I6.

30. Maguire JJ, Davenport AP: $\mathbf{E T}_{\mathbf{A}}$ receptor-mediated constrictor responses to endothelin peptides in human blood vessels in vitro. Br J Pharmacol 1995, I I 5(I): I9|-197.

31. Haynes WG, Strachan FE, Webb DJ: Endothelin $\mathbf{E T}_{\mathbf{A}}$ and $\mathbf{E T}_{\mathbf{B}}$ receptors cause vasoconstriction of human resistance and capacitance vessels in vivo. Circulation 1995, 92(3):357-363.

32. Davenport AP: Update on endothelin receptor nomenclature. Pharmacol Rev 2002, 54(2):219-226.

33. Gregan B, Jürgensen J, Papsdorf G, Furkert J, Schaefer M, Beyermann $M$, Rosenthal $W$, Oksche A: Ligand-dependent differences in the internalization of endothelin $A$ and endothelin $B$ receptor heterodimers. J Biol Chem 2004, 279(26):27679-27687.

34. Sakamoto A, Yanagisawa M, Sawamura T, Enoki T, Ohtani T, Sakurai T, Nakao K, Toyo-oka T, Masaki T: Distinct subdomains of human endothelin receptors determine their selectivity to endothelinA-selective antagonist and endothelinB-selective agonists. J Biol Chem 1993, 268( I 2):8547-8553.

35. Harada N, Himeno A, Shigematsu K, Sumikawa K, Niwa M: Endothelin-I binding to endothelin receptors in the rat anterior pituitary gland: possible formation of an ETA-ETB receptor heterodimer. Cell Mol Neurobiol 2002, 22(2):207-226.

36. Pérez-Rivera AA, Fink GD, Galligan J: Vascular reactivity of mesenteric arteries and veins to endothelin-I in a murine model of high blood pressure. Vascul Pharmacol 2005, 43(I): I- 10 .

37. Ginnan R, Singer HA: CaM kinase II-dependent activation of tyrosine kinases and ERKI/2 in vascular smooth muscle. Am J Physiol Cell Physiol 2002, 282(4):C754-76I.

38. Dulin NO, Niu J, Browning DD, Ye RD, Voyno-Yasenetskaya T: Cyclic AMP-independent activation of protein kinase $A$ by vasoactive peptides. J Biol Chem 200I, 276(24):20827-20830.

39. Kolch W: Coordinating ERK/MAPK signalling through scaffolds and inhibitors. Nat Rev Mol Cell Biol 2005, 6( I I ):827-837.

40. Marshall CJ: Ras effectors. Curr Opin Cell Biol 1996, 8(2): 197-204.

4I. Vanhaesebroeck B, Leevers S, Ahmadi K, Timms J, Katso R, Driscoll $\mathrm{P}$, Woscholski R, Parker P, Waterfield M: Synthesis and function 
of 3-phosphorylated inositol lipids. Annu Rev Biochem 200I, 70:535-602.

42. Force T, Kuida K, Namchuk M, Parang K, Kyriakis JM: Inhibitors of protein kinase signaling pathways: emerging therapies for cardiovascular disease. Circulation 2004, I 09 (10): I I 96- 1205.

43. Pollock DM, Keith TL, Highsmith RF: Endothelin receptors and calcium signaling. FASEB J 1995, 9( I 2): I | 96- I 204.

44. Kawanabe $\mathrm{Y}$, Hashimoto $\mathrm{N}$, Masaki $\mathrm{T}$ : $\mathrm{Ca}(2+)$ channels involved in endothelin-induced mitogenic response in carotid artery vascular smooth muscle cells. Am J Physiol Cell Physiol 2002, 282(2): C330-337.

45. Abraham ST, Benscoter HA, Schworer CM, Singer HA: A role forl calmodulin-dependent protein kinase II in the mitogen-activated protein kinase signaling cascade of cultured rat aortic vascular smooth muscle cells. Circ Res 1997, 8I (4):575-584.

46. Ginnan R, Pfleiderer PJ, Pumiglia K, Singer HA: PKC-delta and CaMKII-delta 2 mediate ATP-dependent activation of ERK I/ 2 in vascular smooth muscle. Am J Physiol Cell Physiol 2004, 286(6): C $128|-| 289$.

47. Kawanabe $\mathrm{Y}$, Hashimoto N, Masaki T: Extracellular Ca2+ influx and endothelin- $I$-induced intracellular mitogenic cascades in rabbit internal carotid artery vascular smooth muscle cells. J Cardiovasc Pharmacol 2002, 40(2):307-3 I4.

48. Adner M, Cantera L, Ehlert F, Nilsson L, Edvinsson L: Plasticity of contractile endothelin-B receptors in human arteries after organ culture. BrJ Pharmacol 1996, II 9(6): I I59-II 66.

Publish with Bio Med Central and every scientist can read your work free of charge

"BioMed Central will be the most significant development for disseminating the results of biomedical research in our lifetime. "

Sir Paul Nurse, Cancer Research UK

Your research papers will be:

- available free of charge to the entire biomedical community

- peer reviewed and published immediately upon acceptance

- cited in PubMed and archived on PubMed Central

- yours - you keep the copyright

Submit your manuscript here:

http://www.biomedcentral.com/info/publishing_adv.asp
BiolMedcentral 